\title{
基于复杂适应系统理论的 㓞性城市设计方法及原则 \\ RESILIENT URBAN DESIGN METHODS AND PRINCIPLES BASED ON THE COMPLEX ADAPTIVE SYSTEM THEORY
}

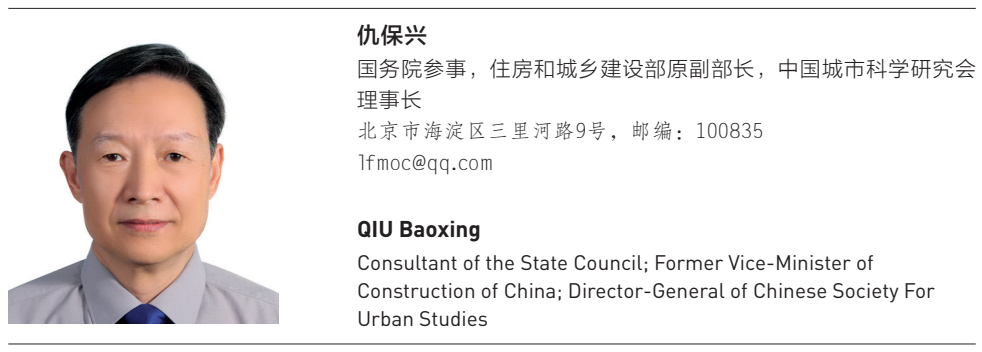

\section{1 城市发展面临的不确定性}

现代城市正面临着越来越多的不确定 性, 而这些不确定性也正在危及城市最根本的 “安全” 问题, 并深刻影响着城市的未来。

首先，面对频发的、前所未有的极端 气候事件, 传统的衡量工具和承载力估算方 法往往收效甚微，严重影响着现有的城市规 划管理措施和基础设施的功效。其次，不可 否认，人工智能、物联网、人工合成生命等 颠覆性新技术、新事物的快速涌现为社会带 来了颠覆性的改变，但其中也暗藏着巨大的 不确定性和脆弱性，这也是人们将 “万物互 联”称作 “风险互联” “危险互联”的原
因。此外, 快速的发展建设也为城市带来了 不确定性，交通的机动化与网络化使得时空 高度压缩, 经济社会全球化使得生产与消 费、需求与供应的波动和影响极易迅速扩大 至更大乃至全球尺度，金融危机就是一个典 型的事例。而人口的大规模迁移也使得城市 的增长速度更加难以预计。最后, 我们的城 市多主体也变得愈加复杂, 高强度的人口流 动使得城市拥有本地城市人口、外来乡村人 口、外国移民等多重人口主体, 人口流动随 着交通工具的发展变得越来越频繁，产生的 冲击也越来越大。很多城市在建设、运行和 发展阶段就面临从农村到城市的巨大突变, 伴随着人口迁移和聚集、建筑物密度增大、

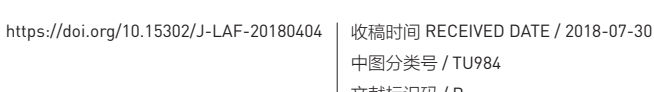

摘要

当前, 城市发展面临的不确定性愈发多样化、复杂化，而认识并适 应不确定性已成为城市规划和设计领域的发展方向之一。“㓞性城市”概 念的提出推进了城市规划设计的科学性和合理性。本文基于第三代系统 论一一复杂适应系统理论, 针对韧性城市设计的方法和原则展开讨论, 提 出主体性、多样性、自治性、适当的午余性、慢变量管理和标识六大要 素，以实现绿色发展、经济活力、城市安全的韧性城市构建目标。 关键词

不确定性；韧性；安全；复杂适应系统；城市发展

\section{ABSTRACT}

Uncertainty exists in the current urban development of contemporary cities and is getting diversified and complicated. Identifying and adapting to such uncertainty is partly defining the future development of urban planning and design. The concept of "resilient city" is developed from the current scientific demands in urban planning and design. This article suggests that Complex Adaptive System as a new system theory would help resilient city planning and construction. According to the Complex Adaptive System theory, a resilient city should possess the adaptability of its components, diversity, autonomy, appropriate redundancy, slow-variable management and identification, in order to improve the ecological, social, and economic resilience and vitality of the city. KEY WORDS

Uncertainty; Resilience; Security; Complex Adaptive System; Urban Development

整理 王皃瑜 苒玲于 汪默英

译 田乐张健

EDITED BY WANG Yinyu RAN Lingyu WANG Moying

TRANSLATED BY Tina TIAN AuguS ZHANG 
图中揭示: 一座城市的 韧性与其坚持力、调遠 力、转型力成正比, 与外界的扰动因素、 脆性因素成反比（图 片来源：援引自参考文 献[1] )

The diagram reveals that the resilience of a city shows a positive correlation with the level of its persistence, level of its persistence
adaptability, and adaptability, and transformatio negatively correlated with the degree with the degree of turbulence and vulnerability Source:
cited from Ref. [1]1.
产业结构调整、区域影响力增强等现象, 灾害 要素以及承载载体密度不断增大, 也由此催生 出更多、更复杂的公共安全新问题。

\section{2 㓞性城市: 应对不确定性的工具}

在上述不可抗拒的城市发展趋势面前, 放大安全圥余或制定预案等传统方式已不能 有效应对随之而来的巨量的不确定性。“㓞 性城市” 概念的提出, 用以定义那些能够吸 收未来的不确定因素对其社会、经济、技术 系统和基础设施的冲击和压力，并维持自身 基本功能、结构、系统和特征的城市。风险
到来时, 韧性城市会自动调整形态, 表现出 高强度的坚持力、调适力和转型力。由图 $1^{[1]}$ 分析可得, 一座城市的韧性与其坚持力、调 适力、转型力成正比, 与外界的扰动因素、 脆性因素成反比。

城市韧性分为结构韧性、过程韧性、系 统韧性三个层面。

结构韧性包括技术韧性、经济韧性、社 会韧性和政府韧性，分别指代基础设施应对 城市灾害、经济结构抵抗金融巨变、社会民 众面对重大事件, 以及政府部门维稳职能运 行并安定民心的能力。

过程韧性是指城市面对大量突发灾害
时, 在维持、恢复和转型三个阶段所表现出 的维持修复能力。在干扰较小时, 发挥主要 作用的是维持力, 以确保系统自主维持平衡 状态，保留原有的功能; 而恢复力则在扰动 较大且已经使系统偏离原平衡态的时候发挥 效力, 以帮助系统在短时间内恢复到原平衡 态; 转型力则是指对风险冲击下暴露的城市 脆弱点进行修正, 并使城市系统达到新的平 衡态的能力。

系统韧性即为城市作为不断运作的活 有机体所具有的韧性。城市有机体由感知系 统、运算系统、执行系统和反馈系统构成, 它能够全面感知各类事件、风险来源和不确 定因素; 将其转译为数据形式投人人工智能 运算, 并基于大数据和机器运算得出各类问 题的解决方案; 随后, 依据方案可以向相关 部门和人员派发指令, 以迅速、精准地解决 问题; 最后，执行结果将被实时反馈，由感 知系统再次感知。由此, 上述 4 个系统形成了 一组闭环控制系统，体现了城市在受到干扰 时自我学习、实时应对和积累经验的能力。

\section{3 复杂适应系统理论：㓞性城市设计的 方法及原则}

基于上述分析及理论，我建议以复杂 适应系统 ( CAS ) 理论为方法论来设计建造 韧性城市。作为第三代系统论的CAS理论, 是在第一代系统论 ( 又称为 “老三论”, 包 括一般系统论、控制论和信息论) 和第二代 系统论 ( 又称为 “新三论” , 包括耗散结构 论、协同论和突变论) 的基础上演变和完善 
的结果。CAS认为, 系统中的每个主体都会 对外界干扰作出自适应反应, 且各种异质的 自适应主体相互之间也会发生复杂作用，二 者均会对系统的演化路径和结构产生影响。 它强调任何系统的变革、演进和发展都是主 体对外部世界的主动认知所产生的集体结 果，而这种存在于持续演进的系统内的 “隐 秩序” 是前两代系统论未能认识到的。

基于CAS理论，一座韧性城市应具备主 体性、多样性、自治性、适当的咒余性、慢变 量管理和标识六大要素, 并平衡兼顾安全韧 性、活力宜居、绿色微循环三大建设目标。

\section{1 主体性}

主体性指系统内的各类主体在环境变 化时所表现出的应对、学习、转型、再成长 等方面的能力。城市系统的主体包含多个层 次，从市民、企业、社团、政府及由它们组 成的建筑、社区、城区到城市整体甚至区 域。城市系统的㓞性即来源于其内部的各类 主体对外界干扰的自适应能力。比如在城市 建筑内引入先进农业技术, 形成一个个能够 高效生产的城市 “微型农场”，既可以丰富 城市食品种类和结构、确保食品来源安全、 形成就地生产－消费模式，亦可以在受到灾 害影响时实现食品应急供给，从而大大提高 城市应对食品短缺问题的能力。

\section{2 多样性}

生态系统拥有的物种和栖息地种类越 多, 抗干扰能力就越强。因此, 要保证城市 生命线的韧性，城市基础设施必须按照分布
式、去中心化和小型化并联式的方式来规划 建设。传统的交通设计存在颇多问题，真正 富有韧性的交通应保证选取任何一种单一出 行方式的人们都能自由畅通地到达目的地。 我们甚至可以在建筑间引人一种架空连廊, 在平时用作慢行绿道, 在洪水时作为紧急生 命通道和避难场所。

\section{3 自治性}

自治性指城市内部不同大小的单元都 能在应对灾害的过程中具有自救或互救的能 力, 或能依靠自身的能力应对或减少风险。 城市是由各类单元按一定层级次序组合而成 的，这些单元的 “自治性” 支撑着城市的韧 性。日本覆盖家庭、社区、城市等多个层级 的地震应急救灾体系和荷兰利用浮力原理和 新型材料研发的自动升降防洪体即为此类典 型案例。

\section{4 适当的圥余性}

为了避免 “剑走边锋” 带来的脆弱性, 城市在基础设施建设中必须要预留出可替 代、并列使用和可自我修补的圥余量，且圥 余量越大，韧性也就越强。例如在家庭、建 筑中引人中水处理系统，自动收集并净化洗 澡水、洗衣水、屋顶雨水等, 用于马桶用 水、灌溉用水等, 将看似无用的水资源统一 收集、分散处理、多级回用, 将能够节约大 量的水资源，有效应对水资源短缺问题

\section{5 慢变量管理}

许多城市脆弱性是 “温水煮青蛙” 造成
的: 在潜移默化的过程中对风险逐渐麻痹, 以致应对能力下降。此类慢变量风险突出表 现在房地产市场热潮和地下燃气管网老化等 几个方面。基于现代信息技术的智慧系统则 可以对人类觉察不到的风险提出预警, 并指 出风险累积的临界点。

\section{6 标识}

人们通过标识来区分各种不同主体的 特征, 实现需求与供给的高效自组织配对, 从而减少因系统整体性和个体性矛盾引发的 雷同性和信息混乱。在标识运用成熟的系统 里, 主体的能动性增强, 在灾害发生时能够 准确区分危险与安全, 从而提高城市抗灾能 力。例如, 在现代科技的帮助下, 利用人脸 识别帮助辨别和跟踪监控罪犯、恐怖分子 等, 可为城市安全提供保障。

\section{4 总结}

传统的城市防灾思维企图建造一道巨大 的 “城市堤坝”, 将各种风险和不确定性拒 之城外, 这不仅是对自然资源和建造材料的 极大浪费, 同时也会衍生出新的脆弱性。传 统工业文明思路下的集中化、大型化、中心 控制化的城市基础设施布局模式存在一定的 片面性和安全隐患, 必须辅之以基于 CAS理 论的新型城市建设模式, 以构建兼顾绿色发 展、经济活力、城市安全的韧性城市。LAF 


\section{The Uncertainty in Urban Development}

Uncertainty exists in the current urban development of contemporary cities and would influence their future trajectories, or even jeopardize cities's security in extreme cases.

The unprecedented frequency of extreme climate events is challenging the conventional measurement tools and city-capacity estimation methods, as well as the current urban planning management means and the effectiveness of urban infrastructures. Besides, the rapid development of technologies like Artificial Intelligence, Internet of Things, and synthetic life has changed contemporary societies and human life, but it has also brought much more uncertainties and vulnerabilities to cities - This is why the "Internet of Everything" is so-called "Internet of Risks" or "Internet of Dangers." The fast urbanization is casting more uncertainty on a city's future - The current urbanization largely relies on the construction of motorized transport network, which has compressed the temporal and spatial dimensions of societies and changed the way that we perceive the world; The socioeconomic globalization tends to easily aggravate the fluctuations of productionconsumption or demand-supply chains into a larger scale, evidenced by the global financial crisis in 2008; The increasingly urban-rural migration and population mobility make city growth difficult to predict; And, the density and mixture of urban residents are so high that complicates the future development of cities. For example, many cities have undergone a dramatic and sudden transformation from rural to urban in its construction, operation, and development, accompanied by population migration and upsurge, intensive urban construction, industrial restructure, changes of a city's regional influence and role, increased disaster hazards and vulnerability, etc., which are all challenging the societal, economic, and ecological security of contemporary cities.

\section{Resilient City: Responding to the Uncertainty in Urban Development}

Conventional urban planning methods, including amplifying security margins or adjusting preliminary plans, often fail to cope with such huge uncertainty. The concept of "resilient city" defines the cities that are capable to alleviate natural and environmental impact and population and development pressure on their social, economic, and technological systems and physical urban infrastructures, while providing fundamental urban services and maintaining functional structures and characteristics. A resilient city is highly adaptive to impacts with a strong capacity to recovery or change. The equations of Robustness of Resilient City System and City Development Resilient Index (Fig. 1) reveal that the resilience of a city shows a positive correlation with the level of its persistence, adaptability, and transformation capacity, while negatively correlated with the degree of turbulence and vulnerability.

The resilience of a city includes three aspects: structural resilience, process resilience, and system resilience.

Structural resilience refers to the resilience in technical, economic, social, and government-policy aspects, respectively an infrastructural capacity to respond to natural disasters and environmental pressures, a healthy economic structure to resist financial impacts, a high public tolerance to social changes, and a governmental agency to effectively provide multiple functions and maintain the societal stability.

Process resilience refers to a city's ability to withstand, recover, and transform from the impact of serious disasters or contingencies. In a withstanding phase, a city's resilience would resist the impact and keep each urban system functioning through a self-adjustment. In a recovery phase, 
when the city is disturbed to a certain degree and fails to function properly, the resilience would help urban systems restore in a short period of time.

And, in a transformation phase, the resilience would help alleviate the city's vulnerabilities and improve the urban systems into a new balanced security pattern.

System resilience refers to the resilience that keeps a city functioning as a living organism, consisting of the sensing mechanism, arithmetic mechanism, operational mechanism, and feedback mechanism, which together make the city capable to predict disasters, risks, and uncertainties with an aid of Artificial Intelligence algorithms by collecting related data and translating it into computational languages to develop responding solutions. Then, detailedplanned roadmaps addressing to specific issues would be implemented through a cooperative work between relevant agencies. Finally, the effects or results would be fed back in real time to the sensing system to inform its future prediction. In this way, the four mechanisms form a loop system that supports a city to have an ability of self-learning, -responding, and -accumulating so that to remedy vulnerabilities and better prepare for future impacts.

\section{The Theory of Complex Adaptive System: Methods and Principles of Resilient Urban Design}

Here, a Complex Adaptive System (CAS) is supposed to design and build resilient cities. CAS is a new system theory derived from the General System Theory, Cybernetics Theory, and Information Theory (also known as the Old Three Frames of System Theory) and the Dissipative Structure Theory, Synergy Theory, and Catastrophe Theory (also known as the New Three Frames of System Theory). CAS suggests that each component in a given system would respond to external disturbances through self-adaption and in an intricate interaction with each other, which dynamically shapes the evolutionary path and the structure of the system. CAS reveals that the transformation or evolution of every system is a collective resultant of all the components' perception on the external world. This "hidden order" is often less discussed by the previous theories.

According to the CAS theory, a resilient city should not only possess the adaptability of its components, diversity, autonomy, appropriate redundancy, slow variable management, and identification, but also guarantee and maximize the city's security, resilience, vitality, livability, and small-scale ecological circulation of resource and energy flows.
3.1 Adaptability of City Components

In a resilient city, all the components - from citizens, enterprises, organizations, and governments of the city, to human construction, communities, and the entire society would be capable of responding and adapting to external changes by selflearning, -recovering, or -transforming. The resilience of a city is defined by the adaption capacity of all the components. For example, by applying technological means and combining with architectural design, a series of "micro urban farms" can be built up in cities, which supports on-site production and consumption, helps increase crop yields and food diversity, and guarantees food security. This micro-scaled urban agricultural network can also improve a city's resilience to food shortage or other impacts caused by climate catastrophes.

\subsection{Diversity}

The more species and habitats an ecosystem has, the stronger its disturbance-tolerance will be. In a resilient city, all key urban infrastructure must be planned and constructed in a decentralized way with a number of small-scaled networks. In comparison with conventional traffic planning and construction methods that are often questioned in accessibility and connectivity, a resilient transport 
planning method should ensure that people can conveniently access to any destination in any commuting means. For instance, a city's buildings can be connected with a sort of skywalk which acts as a pedestrian corridor in dry seasons and an urban shelter during floods.

\subsection{Autonomy}

A city is a sophisticated integration of all urban units, in various scales and forms. Autonomy refers to urban units' ability to self-restore or remedy each other in the process of responding to disasters, or the ability to reduce risks or hazards. Urban units' autonomy would support and enhance the resilience of a city. Examples include Japan's earthquake emergency system that consists of family-, neighborhood-, community-, and city-scaled agencies, and The Netherlands' automatic buoyant flood control system constructed with new materials.

\subsection{Appropriate Redundancy}

A resilient city must reserve adequate space in urban infrastructure construction (a kind of "redundancy") that supports replaceable programs, multi-functional development, selfadaptation and restoration, or any other scenarios; the greater the redundancy a city has, the more resilient it is. For example, the introduction of a domestic water treatment system can support to automatically collect, purify, and reuse bath water, laundry water, roof rainwater, etc. for toilet flushing and irrigation. In this way, domestic sewage can be recycled as a resource, instead of a waste, through decentralized water management system. This strategy will help water saving and cope with water shortage and remediation problems.

\subsection{Slow-Variable Management}

Cities' vulnerability is often aggregated by a "frog-boiling effect": public awareness of hazards slacken and benumb in a subtly changing environment, resulting in a decline in responding capacity. Such slow-variables represented by the boom in the real estate development and the aging of underground gas pipeline networks. A resilient city would employ a smart system based on information technologies to predict risks or potential impacts and identify the related thresholds.

\subsection{Identification}

An identification system is established to distinguish the characteristics of different city components, facilitating an efficient and self-organizing matching of demand and supply to reduce information confusion caused by the contradiction between integrity and individuality. In a developed identification system, the initiative of city components is enhanced, helping more accurately find out the risks and hazards in a disaster and then improving the city's resilience. For example, with the aid of advanced technologies, the use of face-identification systems that help identify criminals, terrorists, etc., can enhance a city's security.

\section{Conclusion}

Conventional disaster prevention ideologies tend to resist the impact of all risks and uncertainties by building a series of "walls" for the city. This not only causes a great cost of natural resources and construction materials, but also brings more vulnerability to the city. The existing centralized, large-scaled, and engineered urban infrastructure construction mode has been proven a failure in coping with contemporary demands nor alleviating the city's vulnerability. The theory of CAS sees a necessity in improving the ecological, social, and economic resilience and vitality of cities. LAF

\section{REFERENCE}

[1] Chen, Z. D. (2017). Research on Resilient City System Theory and Inspiration for China Urban Planning from CAS Perspective (Doctoral dissertation). Tongji University, 1239 Siping Road, Shanghai, China 